\title{
Analysis of Production Quality Control in Minimizing Product Defects with the Six Sigma Method (Case Study at PT. Jaykay Files Indonesia)
}

\author{
$1^{\text {st }}$ Ermayana, $2^{\text {nd }}$ Jeni Sofyan Nur Rosyad \\ ${ }^{1.2}$ Universitas Selamat Sri Kendal, Indonesia \\ Email: ermayana1082@gmail.com
}

\begin{abstract}
PT. JayKay Files Indonesia is a company engaged in the industry that produces files and drills. Where the products have been exported to various countries and the quality is well received by various overseas customers. PT. JayKay Files Indonesia is certified with ISO 9001:2008, OHSAS 18001:2007 and ISO 14001-2004 environmental management system. However, to maintain this quality, the company must control the existing defective products. Then the research was carried out using the Six Sigma DMAIC (Define Measure Analyze Improv Control) stage. And produced 4 (four) types of defects in the Define stage, with the calculation of the sigma value of 3.8 with $3.8 \%$ damage at the measure stage, then Analyze which occurs because there are several causes using a fishbone diagram, namely machine, human, method and environmental factors. At the improve stage, there are several recommendations for improvement so that for control, supervision is carried out at the dept. Quality control.
\end{abstract}

Keywords: Six sigma method, defect, production quality control

\section{INTRODUCTION}

In this industrial era 4.0, business movements are increasing rapidly. This has an impact on business competition that is getting higher and tighter in both the domestic market and the international market. Every business sector is required to always compete with other companies. One of the efforts to be able to excel in the competition or at least survive in the competition is to pay special attention to the quality of the products produced by the company.

According to Sofyan Assauri (in Hayu Kartika, 2013) control and supervision are activities carried out to ensure that production and operating activities are carried out in accordance with what was planned and if deviations occur, these deviations can be corrected so that what is expected can be achieved.

According to Bakhtiar et al (2013) quality control can be interpreted as "activities carried out to monitor activities and ensure actual performance".

Companies that implement quality control can be sure that the quality of the resulting production can also increase. Quality control can be interpreted as an effort made by the company to be able to reduce defective products in one production (Safrizal \& Muhajir, 2016). One of the important criteria that must be considered by consumers in choosing a product is quality. A product is said to have high quality if it can meet the specifications desired by consumers without the slightest defect (Rimantho \& Mariani, 2017).

According to Vincent Gasperz (2005:480), quality control is: "Quality control is the operational techniques and activities used to fulfill requirements for quality".

PT JayKay Files Indonesia is one of the stingy producers that still survives in this 4.0 industrial era. At this time PT JayKay Files Indonesia is faced with the problem of many defective products or there are many defects for slim taper products in the proving division. Until now PT JayKay Files Indonesia does not have the right solution to overcome the problem of defective products that occur. Therefore, PT JayKay Files Indonesia needs to improve quality control with the Six Sigma method, with the theme, "Analysis of Production Quality Control in Minimizing Product Defects with the Six Sigma Method".

\section{RESEARCH METHODS}

The implementation time of this practical work is from January to February 2020. The place where this research was carried out was at PT. JayKay Files Indonesia Semarang. The method used in the quality data processing process uses the Six Sigma method using the Six Sigma method (define, measure, analyze, and improve). is the theoretical basis in accordance with this research. The type of data used in this study is quantitative data which is data that can be calculated, namely data in the form of numbers and supporting information in the form of production cost data of PT JayKay Files Indonesia, which is primary data, namely data obtained from companies and interviews. directly with company employees who are considered related to this research. 
International Journal of Computer and Information System (IJCIS)

Peer Reviewed - International Journal

Vol : Vol. 02, Issue 03, August 2021

e-ISSN : 2745-9659

https://ijcis.net/index.php/ijcis/index

\section{RESULTS AND DISCUSSION}

In the production of Slim Taper at PT. JayKay Files Indonesia found the following types of defects:

a. Forging Process (Broken Handle, Muntir Handle, Flat Handle)

b. Grinding (Hollow, Thick, Thin)

c. Cutting (chopping, Crooked, Not deep enough)

d. Proving (Seam/Laps, Broken Tang, Hollow, Size, Edge Damage, chopping, Level Out, Less Weight, Stamp NotVisible, Bend, Soft, Crack, Broken, Knocking, Dirty, Not Taking Prover, Pitting)

The next step is to determine the CTQ (Critical to Quality). The data used is the Quality Control Department data on the proving process which is the final stage before product packaging. Then determined and simplified CTQ in the proving process as Good Production and Reject. After determining the CTQ (Critical to Quality) then data is collected for 27 days in the proving process to determine the number of defects that occur in one day of the production process. Observations for 27 days can be seen in the table below.

Table 1. Production Results for January

\begin{tabular}{|c|c|c|c|c|c|}
\hline \multirow{2}{*}{ Day } & \multirow{2}{*}{$\begin{array}{c}\text { Production } \\
\text { Quantity }\end{array}$} & \multicolumn{2}{|c|}{ Good condition } & \multicolumn{2}{|c|}{$\begin{array}{c}\text { Reject } \\
\text { Condition } \\
\end{array}$} \\
\hline & & $\begin{array}{c}\text { Amount } \\
\text { (Pcs) }\end{array}$ & $\%$ & $\begin{array}{c}\text { Amount } \\
\text { (Pcs) }\end{array}$ & $\%$ \\
\hline 1 & 20270 & 13058 & $64 \%$ & 7212 & $36 \%$ \\
\hline 2 & 25721 & 21408 & $83 \%$ & 4313 & $17 \%$ \\
\hline 3 & 17460 & 13951 & $80 \%$ & 3509 & $20 \%$ \\
\hline 4 & 24436 & 21143 & $87 \%$ & 3293 & $13 \%$ \\
\hline 5 & 23611 & 19481 & $83 \%$ & 4130 & $17 \%$ \\
\hline 6 & 19776 & 15232 & $77 \%$ & 4544 & $23 \%$ \\
\hline 7 & 21278 & 15843 & $74 \%$ & 5435 & $26 \%$ \\
\hline 8 & 34221 & 29159 & $85 \%$ & 5062 & $15 \%$ \\
\hline 9 & 37514 & 30433 & $81 \%$ & 7081 & $19 \%$ \\
\hline 10 & 19878 & 15767 & $79 \%$ & 4111 & $21 \%$ \\
\hline 11 & 25509 & 21455 & $84 \%$ & 4054 & $16 \%$ \\
\hline 12 & 24698 & 20976 & $85 \%$ & 3722 & $15 \%$ \\
\hline 13 & 33541 & 27862 & $83 \%$ & 5679 & $17 \%$ \\
\hline 14 & 23101 & 18408 & $80 \%$ & 4693 & $20 \%$ \\
\hline 15 & 19321 & 14934 & $77 \%$ & 4387 & $23 \%$ \\
\hline 16 & 14532 & 12231 & $84 \%$ & 2301 & $16 \%$ \\
\hline 17 & 12893 & 7314 & $57 \%$ & 5579 & $43 \%$ \\
\hline 18 & 21440 & 16803 & $78 \%$ & 4637 & $22 \%$ \\
\hline 19 & 36164 & 29843 & $83 \%$ & 6321 & $17 \%$ \\
\hline
\end{tabular}

\begin{tabular}{|l|c|c|c|c|c|}
\hline 20 & 36195 & 29003 & $80 \%$ & 7192 & $20 \%$ \\
\hline 21 & 22496 & 18826 & $84 \%$ & 3670 & $16 \%$ \\
\hline 22 & 4266 & 3971 & $93 \%$ & 295 & $7 \%$ \\
\hline 23 & 31044 & 25620 & $83 \%$ & 5424 & $17 \%$ \\
\hline 24 & 34687 & 29219 & $84 \%$ & 5468 & $16 \%$ \\
\hline 25 & 38296 & 28869 & $75 \%$ & 9427 & $25 \%$ \\
\hline 26 & 30357 & 23536 & $78 \%$ & 6821 & $22 \%$ \\
\hline 27 & 38948 & 34871 & $90 \%$ & 4077 & $10 \%$ \\
\hline total & 691653 & 559216 & $80 \%$ & 132437 & $20 \%$ \\
\hline
\end{tabular}

Source: Data Proving Slim Taper for January

\section{Measure}

At this stage, calculations are carried out to determine the value of DPMO and Sigma. Before that, a control chart is made by calculating the percentage of defects, CL (Control Limit), UCL (Upper Control Limit) and LCL (Lower Control Limit) using a $\mathrm{p}$ control chart.

P control chart has the benefit to help control the quality of production and can provide information about when and where the company should make quality improvements.

The steps for making the $\mathrm{p}$ control chart are:

a. Calculating Damage Percentage

Description:

np: the number of defects in the subgroup

n: number of production in subgroup

Subgroup: Day-

Then the calculation of the data is as follows:

Subgroup-1:

Subgroup-2:

Subgroup-3:

Subgroup-4:

Subgroup-5:

Subgroup-6:

And so on until the subgroup or day 27

b. Calculating the center line (CL)

c. Calculating the Upper Control Limit (UCL)

d. Calculating the Lower Control Limit (LCL)

The complete $\mathrm{p}$ control chart calculation results can be seen in the following table:

Table 2.Calculation of Control Limit P for January 2020 Periode

\begin{tabular}{|l|l|l|l|l|l|l|}
\hline Day & $\begin{array}{c}\text { Production } \\
\text { Quantity }\end{array}$ & $\begin{array}{c}\text { Number of } \\
\text { Defects }\end{array}$ & $\begin{array}{l}\text { Percentage of } \\
\text { Disability (P) }\end{array}$ & CL & UCL & LCL \\
\hline 1 & 20270 & 7212 & 0,3558 & 0,1909 & 0,1998 & 0,1832 \\
\hline 2 & 25721 & 4313 & 0,1677 & 0,1909 & 0,1988 & 0,1841 \\
\hline 3 & 17460 & 3509 & 0,2007 & 0,1909 & 0,2004 & 0,1825 \\
\hline
\end{tabular}


International Journal of Computer and Information System (IJCIS)

Peer Reviewed - International Journal

Vol : Vol. 02, Issue 03, August 2021

e-ISSN : 2745-9659

https://ijcis.net/index.php/ijcis/index

\begin{tabular}{|c|c|c|c|c|c|c|}
\hline 4 & 24436 & 3293 & 0,1347 & 0,1909 & 0,1990 & 0,1839 \\
\hline 5 & 23611 & 4130 & 0,1749 & \begin{tabular}{|l|}
0,1909 \\
\end{tabular} & 0,1992 & 0,1838 \\
\hline 6 & 19776 & 4544 & 0,2283 & \begin{tabular}{|l|l|}
0,1909 \\
\end{tabular} & 0,1999 & 0,1831 \\
\hline 7 & 21278 & 5435 & 0,2544 & \begin{tabular}{|l|}
0,1909 \\
\end{tabular} & 0,1996 & 0,1834 \\
\hline 8 & 34221 & 5062 & 0,1479 & \begin{tabular}{|l|l|}
0,1909 \\
\end{tabular} & 0,1979 & 0,1851 \\
\hline 9 & 37514 & 7081 & 0,1883 & \begin{tabular}{|l|l|l}
0,1909 \\
\end{tabular} & 0,1976 & 0,1854 \\
\hline 10 & 19878 & 4111 & 0,2068 & 0,1909 & 0,1999 & 0,1831 \\
\hline 11 & 25509 & 4054 & 0,1589 & \begin{tabular}{|l|}
0,1909 \\
\end{tabular} & 0,1989 & 0,1841 \\
\hline 12 & 24698 & 3722 & 0,1507 & 0,1909 & 0,1990 & 0,1840 \\
\hline 13 & 33541 & 5679 & 0,1522 & \begin{tabular}{|l|l|}
0,1909 \\
\end{tabular} & 0,1979 & 0,1850 \\
\hline 14 & 23101 & 4693 & 0,2032 & 0,1909 & 0,1992 & 0,1837 \\
\hline 15 & 19321 & 4387 & 0,2271 & 0,1909 & 0,2000 & 0,1830 \\
\hline 16 & 14532 & 2301 & 0,1568 & 0,1909 & 0,2013 & 0,1817 \\
\hline 17 & 12893 & 5579 & 0,4328 & \begin{tabular}{|l|}
0,1909 \\
\end{tabular} & 0,2019 & 0,1811 \\
\hline 18 & 21440 & 4637 & 0,2336 & \begin{tabular}{|l|l|}
0,1909 \\
\end{tabular} & 0,1995 & 0,1834 \\
\hline 19 & 36164 & 6321 & 0,1751 & \begin{tabular}{|l}
0,1909 \\
\end{tabular} & $\mid 0,1977$ & 0,1853 \\
\hline 20 & 36195 & 7192 & 0,1987 & 0,1909 & 0,1977 & 0,1853 \\
\hline 21 & 22496 & 3670 & 0,1631 & \begin{tabular}{|l|l|}
0,1909 \\
\end{tabular} & 0,1993 & 0,1836 \\
\hline 22 & 4266 & 295 & 0,0689 & \begin{tabular}{|l|}
0,1909 \\
\end{tabular} & 0,2096 & 0,1734 \\
\hline 23 & 31044 & 5424 & 0,1747 & \begin{tabular}{|l|l|}
0,1909 \\
\end{tabular} & 0,1982 & 0,1848 \\
\hline 24 & 34687 & 5468 & 0,1576 & \begin{tabular}{|l}
0,1909 \\
\end{tabular} & 0,1978 & 0,1851 \\
\hline 25 & 38296 & 9427 & 0,2442 & 0,1909 & 0,1975 & 0,1854 \\
\hline 26 & 30357 & 6821 & 0,2247 & \begin{tabular}{|l|}
0,1909 \\
\end{tabular} & 0,1983 & 0,1847 \\
\hline 27 & 38948 & 4077 & 0,1047 & \begin{tabular}{|l|l|}
0,1909 \\
\end{tabular} & 0,1975 & 0,1855 \\
\hline total & 691653 & 132436 & & & & \\
\hline $\begin{array}{l}\text { aver } \\
\text { age }\end{array}$ & 25617 & 4905 & & & 0,1994 & 0,1836 \\
\hline
\end{tabular}

Source: Table of Calculation Results of the Control

Map Formula $\mathrm{p}$

From the results of the calculation table above, Based on the table above, it is known that the highest probability of defects is on the 17th day of observation, which is 0.4328 and the lowest probability of defects is on the $22 \mathrm{nd}$ day, which is 0.0689 . For the control limit, the result is 0.1915 , the upper control limit is 0.1994 and the lower control limit is 0.1836. Next, a P Control Map is made which can be seen in the $\mathrm{P}$ control chart image on the next page.

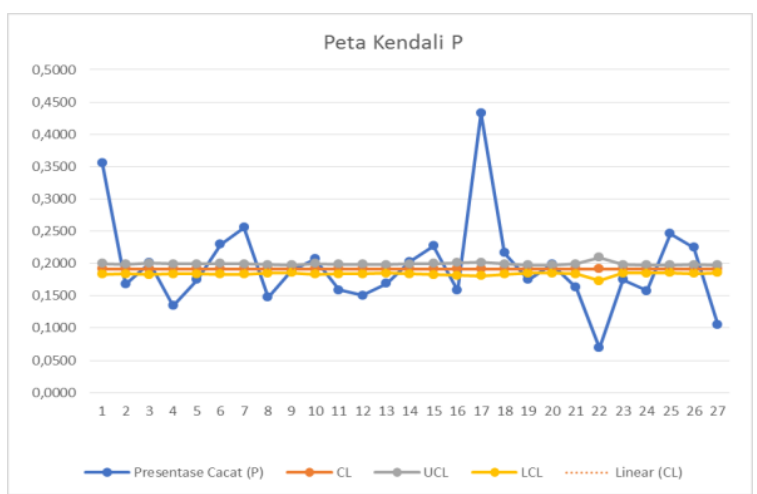

Figure 1. P Control Map

Based on the picture of the control chart $\mathrm{p}$ above, it can be seen that the data obtained are not entirely within the control limits that have been set, even many are out of the control limits, only 1 (one) point is within the control limits, so it can be said that the process is not under control. In the picture above, it can be seen that the 27 samples taken fall into the control limits. The highest value is on the 17 th day and the lowest is on the 22nd day. This indicates that there is a high deviation. It states that quality control at PT. JayKay Files Indonesia needs improvement. Because there are very high and irregular fluctuating points which indicate that the production process is still experiencing deviations.

The next calculation is the measurement of sigma performance with the aim of knowing the current level of work (performance baseline). Performance baseline as a unit of measurement in Defect Per Million Opportunities (DPMO) or sigma capability level (Defrianto \& Farida). The calculation stages start from DPO, DPMO, and Sigma Value. Defect Per Opportunities (DPO) is a measure of failure calculated in a six sigma quality improvement program which shows the number of defects or failures per opportunity.

$$
\begin{aligned}
& \text { Subgrup-1: } D P O=\frac{7212}{20270 \times 16}=0,022237 \\
& \text { Subgrup-2: } D P O=\frac{4313}{25721 \times 16}=0,010480 \\
& \text { Subgrup-3: } D P O=\frac{3509}{17460 \times 16}=0,012561 \\
& \text { Subgrup-4: DPO }=\frac{3293}{24436 \times 16}=0,008423 \\
& \text { Subgrup-5: DPO }=\frac{4130}{23611 \times 16}=0,010932 \\
& \text { Subgrup- : DPO }=\frac{4544}{19776 \times 16}=0,014361
\end{aligned}
$$


International Journal of Computer and Information System (IJCIS)

Peer Reviewed - International Journal

Vol : Vol. 02, Issue 03, August 2021

e-ISSN : 2745-9659

https://ijcis.net/index.php/ijcis/index

And so on until the 27th subgroup

Usually this DPO when associated with a constant of 1,000,000 will become DPMO (Defect Per Million Opportunities) with the formula:

$D P M O=D P O \times 1.000 .000$

The DPMO value is converted to a sigma value using Microsoft excel with the calculation formula:

DPMO Value Conversion =

NORMSINV $((1,000,000-D P M O) / 1,000,000)+1,5$

The following is a table of the results of the calculation of DPO, DPMO and Sigma Value:

Table 3. Calculation of DPMO Value \& Sigma Value

\begin{tabular}{|l|l|l|l|l|l|l|}
\hline No & $\begin{array}{c}\text { Production } \\
\text { Quantity }\end{array}$ & $\begin{array}{c}\text { Number } \\
\text { of Defects }\end{array}$ & $\begin{array}{c}\text { Probability } \\
\text { of Disability } \\
\text { (p) }\end{array}$ & DPO & DPMO & $\begin{array}{c}\text { Sigma } \\
\text { Value }\end{array}$ \\
\hline 1 & 20270 & 7212 & 0,3558 & 0,022237 & 22237 & 3,5 \\
\hline 2 & 25721 & 4313 & 0,1677 & 0,010480 & 10480 & 3,8 \\
\hline 3 & 17460 & 3509 & 0,2010 & 0,012561 & 12561 & 3,7 \\
\hline 4 & 24436 & 3293 & 0,1348 & 0,008423 & 8423 & 3,9 \\
\hline 5 & 23611 & 4130 & 0,1749 & 0,010932 & 10932 & 3,8 \\
\hline 6 & 19776 & 4544 & 0,2298 & 0,014361 & 14361 & 3,7 \\
\hline 7 & 21278 & 5435 & 0,2554 & 0,015964 & 15964 & 3,6 \\
\hline 8 & 34221 & 5062 & 0,1479 & 0,009245 & 9245 & 3,9 \\
\hline 9 & 37514 & 7081 & 0,1888 & 0,011797 & 11797 & 3,8 \\
\hline 10 & 19878 & 4111 & 0,2068 & 0,012926 & 12926 & 3,7 \\
\hline 11 & 25509 & 4054 & 0,1589 & 0,009933 & 9933 & 3,8 \\
\hline 12 & 24698 & 3722 & 0,1507 & 0,009419 & 9419 & 3,8 \\
\hline 13 & 33541 & 5679 & 0,1693 & 0,010582 & 10582 & 3,8 \\
\hline 14 & 23101 & 4693 & 0,2032 & 0,012697 & 12697 & 3,7 \\
\hline 15 & 19321 & 4387 & 0,2271 & 0,014191 & 14191 & 3,7 \\
\hline 16 & 14532 & 2301 & 0,1583 & 0,009896 & 9896 & 3,8 \\
\hline 17 & 12893 & 5579 & 0,4327 & 0,027045 & 27045 & 3,4 \\
\hline 18 & 21440 & 4637 & 0,2163 & 0,013517 & 13517 & 3,7 \\
\hline 19 & 36164 & 6321 & 0,1748 & 0,010924 & 10924 & 3,8 \\
\hline 20 & 36195 & 7192 & 0,1987 & 0,012419 & 12419 & 3,7 \\
\hline 21 & 22496 & 3670 & 0,1631 & 0,010196 & 10196 & 3,8 \\
\hline 22 & 4266 & 295 & 0,0692 & 0,004322 & 4322 & 4,1 \\
\hline 23 & 31044 & 5424 & 0,1747 & 0,010920 & 10920 & 3,8 \\
\hline 24 & 34687 & 5468 & 0,1576 & 0,009852 & 9852 & 3,8 \\
\hline 25 & 38296 & 9427 & 0,2462 & 0,015385 & 15385 & 3,7 \\
\hline
\end{tabular}

\begin{tabular}{|c|c|c|c|c|c|c|}
26 & 30357 & 6821 & 0,2247 & 0,014043 & 14043 & 3,7 \\
\hline 27 & 38948 & 4077 & 0,1047 & 0,006542 & 6542 & 4,0 \\
\hline Total & 691653 & 132437 & 5,292977 & & & \\
\hline average & 25617 & 4905 & 0,1960 & 0,0123 & 12252 & 3,8 \\
\hline
\end{tabular}

In the table above, it can be seen that the production of Slim Taper at PT. JayKay Files Indonesia has an average production rate of 25617 pcs per day with an average defect or damage rate of 4905 Slim Tapers per day or a probability of 0.1960 . The DPMO value is 12252 , which means that the probability of damage per 1 million units is 12252 . For the sigma value, the result is 3.8 , which means that in each production process there will be no defects or damage of more than $3.8 \%$. Based on these results it can be seen that PT. JayKay Files Indonesia needs to improve the production process so that the level of defects or damage can be minimized. The following is a table of the level of achievement of the sigma value.

Table 4. Level of Achievement of Sigma Nilai Value

\begin{tabular}{|l|l|}
\hline $\begin{array}{c}\text { Sigma Achievement } \\
\text { Level }\end{array}$ & \multicolumn{1}{|c|}{ DPMO } \\
\hline 1-Sigma & 691.462 \\
\hline 2-Sigma & $\begin{array}{l}\text { 308.538 (Indonesian industry } \\
\text { average) }\end{array}$ \\
\hline 3-Sigma & 66.807 \\
\hline 4-Sigma & 6.210 (USA industry average) \\
\hline 5-Sigma & $\begin{array}{l}233 \text { (Japanese industrial } \\
\text { average) }\end{array}$ \\
\hline 6-Sigma & 3.4 (World class industry) \\
\hline
\end{tabular}

\section{Analyze}

This stage is carried out by analyzing Pareto diagrams based on data that has been processed to determine the percentage of types of defective products and the order of types of damage that occur from the lowest to the highest in the Slim Taper production process at PT. JayKay Files Indonesia. The following is a table for calculating the percentage of types of defects:

Table 5. Calculation of the Percentage of Types of Defects

\begin{tabular}{|c|c|c|c|c|}
\hline \multicolumn{2}{|l|}{ Jenis Cacat } & \multirow{2}{*}{ Frekuensi } & \multirow{2}{*}{ Presentase } & \multirow{2}{*}{ Akumulas } \\
\hline Keterangan & Simbol & & & \\
\hline Seam/Laps & A & 54 & $0,04 \%$ & $0,04 \%$ \\
\hline $\begin{array}{l}\text { Broken } \\
\text { Tang }\end{array}$ & B & 5934 & $4,48 \%$ & $4,52 \%$ \\
\hline
\end{tabular}


International Journal of Computer and Information System (IJCIS)

Peer Reviewed - International Journal

Vol : Vol. 02, Issue 03, August 2021

e-ISSN : 2745-9659

https://ijcis.net/index.php/ijcis/index

\begin{tabular}{|l|c|l|l|l|} 
Hollow & $\mathrm{C}$ & 1073 & $0,81 \%$ & $5,33 \%$ \\
\hline Size & $\mathrm{D}$ & 2581 & $1,95 \%$ & $7,28 \%$ \\
\hline $\begin{array}{l}\text { Edging } \\
\text { Damage }\end{array}$ & $\mathrm{E}$ & 17094 & $12,91 \%$ & $20,19 \%$ \\
\hline Chopping & $\mathrm{F}$ & 11113 & $8,39 \%$ & $28,58 \%$ \\
\hline Level Out & $\mathrm{G}$ & 12727 & $9,61 \%$ & $38,19 \%$ \\
\hline $\begin{array}{l}\text { Less } \\
\text { Weigth }\end{array}$ & $\mathrm{H}$ & 288 & $0,22 \%$ & $38,41 \%$ \\
\hline $\begin{array}{l}\text { Stamp } \\
\text { NotViasible }\end{array}$ & $\mathrm{I}$ & 1662 & $1,25 \%$ & $39,66 \%$ \\
\hline Bend & $\mathrm{J}$ & 7863 & $5,94 \%$ & $45,60 \%$ \\
\hline Soft & $\mathrm{K}$ & 17995 & $13,59 \%$ & $59,19 \%$ \\
\hline Crack & $\mathrm{L}$ & 28012 & $21,15 \%$ & $80,34 \%$ \\
\hline $\begin{array}{l}\text { Broken } \\
\text { Knocking }\end{array}$ & $\mathrm{M}$ & 643 & $0,49 \%$ & $80,82 \%$ \\
\hline Dirty & $\mathrm{N}$ & 14016 & $10,58 \%$ & $91,41 \%$ \\
\hline $\begin{array}{l}\text { Not Taking } \\
\text { Prover }\end{array}$ & $\mathrm{O}$ & 4065 & $3,07 \%$ & $94,48 \%$ \\
\hline Pitting & $\mathrm{P}$ & 7315 & $5,52 \%$ & $100,00 \%$ \\
\hline Total & 16 & 132436 & $100,00 \%$ & \\
\hline Source: Resulf & $\mathrm{n}$ & \\
\hline
\end{tabular}

Source: Results of proving data for January

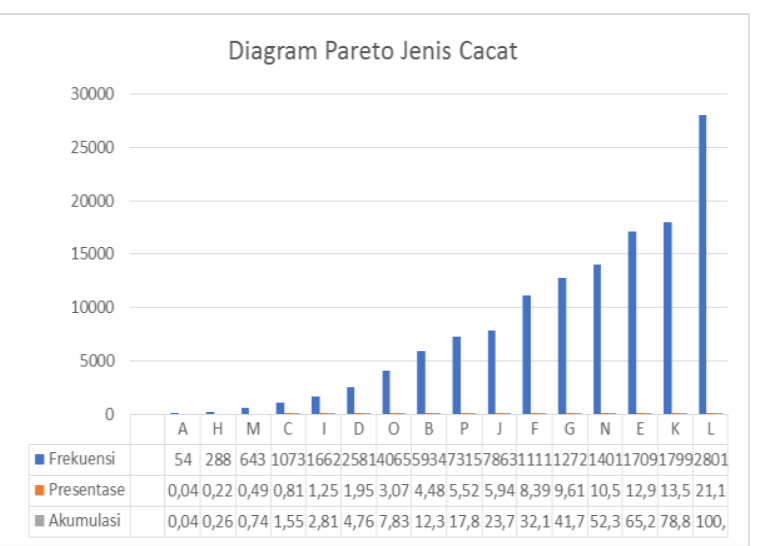

Figure 2. Pareto Chart

From the Pareto diagram above, it can be seen that the type of defect L (Crack) is the type of defect with the highest percentage of $21.15 \%$, the second is $\mathrm{k}$ (Soft) with a percentage of $13.59 \%$ and the third is E (Edging Damage) with a percentage of 12, 91\% and so on as in the table above. After knowing the type of defect, the next step is to identify the cause of the type of defect using a fishbone.

There are four main causes of several types of defects that can occur due to machine, human, method and environmental factors. The following is an explanation of each of the factors that cause defects:

1. Machine

Machine factors that affect defective products are matters relating to the use of equipment or machines and their reusability such as the age of the machine which is no longer economical and the lack of maintenance for machine maintenance.

2. Man

Human factors are related to labor or personnel aspects such as lack of skills, lack of experience, and physical fatigue.

3. Method

Factors regarding work methods and procedures that can result in defective products include SOP errors and lack of training.

4. Environment

Work environment factors also affect the quality of the product. A good environment will make workers more comfortable and minimize defective products. Environmental factors that affect, among others, noise, and vibration.

\section{Improve}

At the improve stage, recommendations for improvement of each cause of defects that have been made through fishbone diagrams are given. The following are recommendations for improvements that can be made by PT. JayKay Files Indonesia in an effort to improve the quality of Slim Taper products:

Table 6.Recommendations for Improvement of each Cause of Disability

\begin{tabular}{|l|l|l|}
\hline No & \multicolumn{1}{|c|}{$\begin{array}{c}\text { Causes of } \\
\text { Defects }\end{array}$} & \multicolumn{1}{|c|}{ Recommendations Repair } \\
\hline 1 & Lack of training & $\begin{array}{l}\text { Hold training activities or } \\
\text { workshops related to the work to be } \\
\text { carried out }\end{array}$ \\
\hline 2 & SOP Error & $\begin{array}{l}\text { Conduct regular evaluations if } \\
\text { necessary changes or adjustments to } \\
\text { SOPs }\end{array}$ \\
\hline 3 & Fatigue & Optimal work and rest time planning \\
\hline 4 & Less Skilled & $\begin{array}{l}\text { Setting worker acceptance standards } \\
\text { Do more intensive training }\end{array}$ \\
\hline 5 & $\begin{array}{l}\text { Lack of } \\
\text { experience }\end{array}$ & $\begin{array}{l}\text { Carry out routine checks regarding } \\
\text { machine effectiveness }\end{array}$ \\
\hline 6 & $\begin{array}{l}\text { Less } \\
\text { Maintenance }\end{array}$ & $\begin{array}{l}\text { Schedule maintenance on a regular } \\
\text { basis }\end{array}$ \\
\hline 8 & Noise & $\begin{array}{l}\text { Using lighting standards according } \\
\text { to the regulation of the Minister of } \\
\text { Manpower No. 5 of 2018 } \\
\text { concerning Occupational Safety and } \\
\text { Health in the Work Environment }\end{array}$ \\
\hline 9 & vibration &
\end{tabular}

\section{Control}

The last stage is controlling the improvement recommendations that have been given. Supervision needs to be carried out to see if there are differences in the quality of Slim Taper before and after the implementation of several recommendations. PT. JayKay Files Indonesia, especially the Quality Control Department, tries to implement some of the 
recommendations given so that the increase in sigma value can be achieved so that the quality of Slim Taper products at PT. JayKay Files Indonesia has increased and the percentage of defective products can be reduced.

\section{CONCLUSIONS AND SUGGESTIONS}

\section{Conclusion}

1. The results of the calculation of the quality control of Slim Taper products at PT. JayKay Files Indonesia with the Six Sigma method:

a. Based on the processed data, the results of the DPMO calculation are 12252 , which means that there is a probability of a defective product of 12252 out of one million possibilities and a sigma value of 3.8 is obtained which means that in each production process there will be no defects or damage of more than $3,8 \%$.

b. The types of damage or defects that often occur in the production of Slim Taper PT. JayKay Files Indonesia is caused by Crack as much as $21.15 \%$, the second is Soft with a percentage of $13.59 \%$ and the third is Edging Damage with a percentage of $12.91 \%$.

2. The application of the six sigma method in calculating the quality control of Slim Taper products produces complete, precise and accurate data according to the data needs of the Quality Control department.

\section{Suggestions}

1. Companies need to use the six sigma method to be able to find out the types of damage that often occur and the factors that cause it. Thus the company can immediately take preventive action to reduce the occurrence of product defects.

2. Based on the analysis using the six sigma method that has been carried out, the company can make quality improvements by focusing on repairs to types of damage that have a large or dominant number in production, which are caused by factors such as; people, machines, methods, and the environment.

\section{REFERENCES}

[1.] Bakhtiar, S.; Tahir, S.; dan Hasni, R.A. 2013. Analisa pengendalian kualitas dengan menggunakan metode statistical quality control (SQC). Malikussaleh Industrial Engineering Journal. Vol 2 (1), pp.: 29-36.

[2.] Irwan., dan Haryono, D. 2015. Pengendalian Kualitas Statistik (Pendekatan Teoritis dan Aplikatif). Bandung: Penerbit Alfabeta.

[3.] Kartika, H. 2013. Analisis pengendalian kualitas produk CPE film dengan metode statistical process control pada PT. MSI. Jurnal Ilmiah Teknik Industri. Vol. 1 (1), pp.: 50-58.

[4.] Munjiati, M. 2015. Manajemen Operasi. Yogyakarta: LP3M.

[5.] Nastiti, Heni. 2014. Analiss Pengendalian Kualitas Produk dengan Metode SQC. Jurnal Manajemen Mutu Vol 6 No 1.

[6.] Render, B., dan J, Heizer. 2013. Operation Management-Manajemen Operasi. Edisi 11. Jakarta: Salemba Empat.

[7.] Rimantho, D. \& Mariani, D. M. 2017. Penerapan Metode Six Sigma Pada Pengendalian Kualitas Air Baku Pada Produksi Makanan. Jurnal Ilmiah Teknik Industri, $1-22$.

[8.] Safrizal, \& Muhajir. 2016. Pengendalian Kualitas dengan Metode Six Sigma. Jurnal dan Keuangan. 615-626.

[9.] Vincent, Gaspersz. 2005. Total Quality Management. Jakarta: PT. Gramedia Pustaka Utama.

[10.] Wulandari, S..D., dan Amelia. 2012. Pengendalian Kualitas Produksi di PT. Nutrifood Indonesia Dalam Upaya Mengendalikan Tingkat Kerusakan (Defect) Dus Produk Sweetener Dengan Menggunakan Statistical ProcesControl (SPC). Economicus, vol 05, hal 37, STIE Dewantara.

[11.] Zulian Yamit. 2013. Manajemen Kualitas Produk \& Jasa. Yogyakarta: Ekonisia. 